\title{
Attitudes and knowledge of Health care workers in Cieszyn County of the Silesian Province in southern Poland about seasonal flu vaccinations - preliminary study
}

\author{
Postawy i wiedza pracowników ochrony zdrowia powiatu cieszyńskiego \\ na temat sezonowych szczepień przeciwko grypie - doniesienie wstępne
}

\author{
Anna Michalik ${ }^{1, A-D, F} \oplus$, Katarzyna Gawlik ${ }^{1, A-C, E \oplus}$ \\ ${ }^{1}$ Faculty of Health Sciences, University of Bielsko-Biala, Poland \\ A - Research concept and design, B - Collection and/or assembly of data, C - Data analysis and interpretation, \\ $D$ - Writing the article, E-Critical revision of the article, F - Final approval of article \\ Attitudes and knowledge of Health care workers in Cieszyn County of the Silesian Province in southern Poland about seasonal flu vaccinations \\ - preliminary study. Med Og Nauk Zdr. 2020; 26(1): 35-41. DOI: 10.26444/monz/115121
}

\begin{abstract}
Introduction. Influenza is one of the more common viral infectious diseases, the occurrence of which is a significant clinical, epidemiological and economic problem. According to reports from the World Health Organization (WHO), around 5\% $-10 \%$ of adults and $20 \%-30 \%$ of children fall ill worldwide every year. During the year, 3-5 million acute cases are registered, and around $250,000-650,000$ people die. The annual influenza vaccine is the best method of preventing the disease. Health care workers are a risk group for influenza.

Objective. The aim of the survey was to assess the knowledge and attitudes towards vaccination among health care workers (HCWs).

Materials and method. The study was conducted among a group of 330 randomly selected employees of medical facilities in the Cieszyn County of the Silesian Province in southern Poland. The research tools were a self-made questionnaire and a knowledge test. To assess the statistical significance of differences in qualitative data between the groups, the chi independence test was applied.

Results. $47.6 \%$ of the respondents had a low-level of knowledge about flu vaccination, in $41.8 \%$ it was at the medium level, and in only $10.6 \%$ the knowledge level was high. The average number of points scored in the knowledge test was $4.44(S D=2.33$ ) out of 12 points possible. Only every third respondent was in favour of the vaccination. Slightly over $15 \%$ of the respondents $(17.60 \%)$ were vaccinated against influenza in the current 2018-2019 season.

Conclusions. Knowledge about vaccination against influenza is incomplete. A small percentage of health care professionals are in favour of influenza vaccination. There is a need to increase efforts to promote annual influenza vaccination among health care professionals.
\end{abstract}

\section{Key words}

influenza vaccination, health care worker, attitude, knowledge, beliefs

\section{Streszczenie}

Cel pracy. Grypa jest jedną z najczęściej występujących wirusowych chorób zakaźnych, stanowiących istotny problem kliniczny, epidemiologiczny i ekonomiczny. Według raportów Światowej Organizacji Zdrowia (WHO) każdego roku choruje na nią ok. 5-10\% dorosłych i 20-30\% dzieci na całym świecie. W ciągu roku rejestruje się 3-5 mln ostrych przypadków, a ok. 250 -650 tys. osób umiera. Coroczne szczepienie przeciw grypie jest najlepszą metodą zapobiegania tej chorobie. Pracownicy ochrony zdrowia stanowią grupę ryzyka zachorowania na grypę. Celem pracy była ocena wiedzy i postaw wobec szczepień wśród pracowników służby zdrowia (HCW).

Materiał i metody. Badania zostały przeprowadzone w grupie 330 losowo wybranych pracowników placówek medycznych na terenie powiatu cieszyńskiego województwa śląskiego. Narzędzie badawcze stanowił kwestionariusz ankiety własnego autorstwa oraz test wiedzy. Aby ocenić statystyczną istotność różnic danych jakościowych pomiędzy grupami, zastosowano test niezależności chi².

Wyniki. 47,6\% respondentów posiadało wiedzę na temat szczepień przeciwko grypie na poziomie niskim, 41,8\% na poziomie średnim, a tylko 10,6\% na poziomie wysokim. Średnia liczba punktów w teście wiedzy wyniosła 4,44 $(S D=2,33)$ na 12 pkt możliwych. Tylko co trzeci respondent był zwolennikiem szczepienia. Niewiele ponad 15\% badanych (17,60\%) zaszczepiło się przeciw grypie w sezonie 2018/2019.

Wnioski. Wiedza na temat szczepienia przeciwko grypie jest niepełna. Niewielki odsetek pracowników ochrony zdrowia jest zwolennikiem szczepienia przeciwko grypie. Istnieje konieczność zwiększenia działań promujących coroczne szczepienie przeciwko grypie wśród pracowników ochrony zdrowia.

\section{Słowa kluczowe}

wiedza, postawa, przekonania, szczepienie przeciwko grypie, pracownik ochrony zdrowia 


\section{INTRODUCTION}

Influenza is one of the more common viral infectious diseases, the occurrence of which is a significant clinical, epidemiological and economic problem. According to the World Health Organization (WHO) reports, around 5\%-10\% of adults and $20 \%-30 \%$ of children fall ill worldwide every year. Each year, 3-5 million acute cases are registered, and around 250,000-650,000 people die $[1,2]$. Flu is a disease in which the constant evolution of the virus contributes to the occurrence of serious seasonal epidemics as a result of point mutations [3]. Due to their contact with influenza patients and the ease of transmission of the influenza virus, medical personnel are particularly vulnerable to infection. The risk of transmission of infection from influenza health care workers to patients is also a big problem. This is especially dangerous for chronically ill persons, the elderly, pregnant women, newborns and young children, who are at high risk of the severe course of the disease. Vaccination of medical personnel against flu is therefore associated not only with a reduced risk of severe consequences of the disease in the vaccinated, but also all those who have contact with them. For this reason, health workers are considered to be an important link and a priority target for influenza vaccination [4]. According to the American Advisory Committee on Immunization Practices (ACIP), vaccinating medical workers against influenza, as in other groups, should be carried out every year [5]. Similar recommendations were included in the Polish Preventive Vaccination Programme, according to which the vaccination against influenza is recommended to employees of medical facilities and administrative staff of these facilities [6]. Despite the awareness of the dangers of flu and its complications, the problem is the small percentage of health care workers undergoing influenza vaccination every year. It is estimated that in Poland only $5-6 \%$ of medical workers are vaccinated against influenza, which is one of the lowest rates in Europe [7].

\section{OBJECTIVE}

The aim of the study was to assess the attitudes and knowledge about influenza vaccination among healthcare workers.

\section{MATERIALS AND METHOD}

The study was conducted among employees of medical facilities in Cieszyn County of the Silesian Province in southern Poland, whose management agreed to the carrying out of the survey. The criterion for inclusion in the study was consent and being a healthcare worker. The survey was conducted in the 2018-2019 season, from December 2018 - March 2019, among nurses, midwives, doctors, paramedics and physiotherapists. The research tool was a self-made questionnaire, consisting of 17 closed questions and a knowledge test, containing 5 questions, both closed and open, multiple-choice, concerning the main research problem, and developed on the basis of available literature. For every correct answer the respondents were awarded 1 point, with the maximum of 12 points for the whole test. The number of points in relation to each person was added and then converted into a percentage scale from $0-100$, where the score of 100 meant that the surveyed person provided the correct answers. The results obtained were then converted into ranges: the respondents who obtained no more than 35\% of the points were qualified to the group of persons with a low level of knowledge, those who answered correctly to $36-60 \%$ of the questions - to the group of persons with a medium level of knowledge, and those who obtained at least $61 \%$ of correct answers - to the group of persons with a high level of knowledge.

Based on the number of employed health care workers meeting the criteria for inclusion, 600 questionnaires were individually distributed, of which 330 (55\%) were returned.

Due to the heterogeneity of groups in relation to the variables of age, profession, education, internship and workplace, the answers were merged, resulting in 3 categories regarding age (below 40 years of age, $40-49$ years old, and over 50) and 2 categories in relation to occupation (nurse and other medical profession), education (secondary and higher), work experience (less or more than 15 years). Those working in the departments of internal medicine, dermatology, nephrology, neurology, ophthalmology, cardiology, rehabilitation, paediatrics, geriatrics, infectious and intensive care, were classified as conservative wards, while the departments of general surgery, trauma-orthopaedic, gynaecologicalobstetric, paediatric surgery, operating theatres and hospital emergency department, were classified as surgical wards.

The majority of the respondents were women $(88.8 \%)$. The largest group of the respondents were persons aged 45-49 (18.20\%), then 50-54 (17.00\%) and 40-44 (16.40\%). Nurses constituted the vast majority of the respondents (73.60\%). Almost half of the respondents $(47.90 \%)$ declared having secondary education. $63.90 \%$ of those surveyed had over 15 years of work experience. The detailed characteristics of the studied group are presented in Table I.

\section{RESULTS}

The results obtained were entered into the Excel 2016 spreadsheet, while the statistical calculations were made using the SPSS (Statistical Package for the Social Sciences) 24.0.0.1 Software. The maximum allowable type I error was assumed to be $\alpha=0.05$ for all analyses, and a value was considered statistically significant when $p \leq 0.05$. To assess the statistical significance of differences in qualitative data between the groups, the chi independence test was used ${ }^{2}$. The choice of the test was dictated by the nature of the variables involved in the analysis. In each case, these were qualitative variables (measured at the nominal or ordinal level).

As for the knowledge level of surveyed, $47.6 \%$ of the respondents had a low-level of knowledge of flu vaccination, in $41.8 \%$ it was at the medium level, and in only $10.6 \%$ at the high level. The average number of points in the knowledge test was 4.44 points $(\mathrm{SD}=2.33$ ) out of 12 achievable (Tab. 2$)$. Detailed analysis of the answers given in the knowledge test showed that almost $80 \%$ of the respondents $(79.10 \%)$ knew that seasonal influenza vaccination is recommended to health care professionals. $90 \%$ of the respondents believed that medical personnel are exposed to influenza virus infection through droplet transmission, and almost $30 \%(27.27 \%)$ through physical contact. As far as influenza complications were concerned, the most frequently listed were cardiological (78.42\%) and pulmonary (68.39\%). Every 
Table 1. General characteristics of the studied group

\begin{tabular}{|c|c|c|}
\hline Sex & $\mathbf{N}$ & $\%$ \\
\hline Women & 293 & 88,80 \\
\hline Men & 37 & 11,20 \\
\hline \multicolumn{3}{|l|}{ Age [years] } \\
\hline $25-29$ & 49 & 14,80 \\
\hline $30-34$ & 26 & 7,90 \\
\hline $35-39$ & 27 & 8,20 \\
\hline $40-44$ & 54 & 16,40 \\
\hline $45-49$ & 60 & 18,20 \\
\hline $50-54$ & 56 & 17,00 \\
\hline $55-59$ & 49 & 14,80 \\
\hline $60-64$ & 7 & 2,10 \\
\hline$>65$ & 2 & 0,60 \\
\hline \multicolumn{3}{|l|}{ Profession } \\
\hline Nurse & 243 & 73,60 \\
\hline Midwife & 12 & 3,60 \\
\hline Paramedic & 23 & 7,00 \\
\hline Physician & 28 & 8,50 \\
\hline Physiotherapist & 9 & 2,70 \\
\hline Other & 15 & 4,50 \\
\hline \multicolumn{3}{|l|}{ Education } \\
\hline Vocational & 4 & 1,20 \\
\hline Secondary & 158 & 47,90 \\
\hline Higher vocational & 60 & 18,20 \\
\hline Higher & 108 & 32,70 \\
\hline \multicolumn{3}{|l|}{ Workplace } \\
\hline General surgery department & 19 & 5,80 \\
\hline Trauma and orthopedic department & 25 & 7,60 \\
\hline Internal medicine department & 31 & 9,40 \\
\hline Intensive care unit & 31 & 9,40 \\
\hline Gynecological-obstetrics department & 8 & 2,40 \\
\hline Pediatric ward & 50 & 15,20 \\
\hline Nephrology department & 6 & 1,80 \\
\hline Emergency ward & 40 & 12,12 \\
\hline Pediatric surgery ward & 7 & 2,10 \\
\hline Operating room & 11 & 3,30 \\
\hline Dermatological ward & 9 & 2,70 \\
\hline Geriatric ward & 11 & 3,30 \\
\hline Cardiology department & 8 & 2,40 \\
\hline Neurology department & 13 & 4,00 \\
\hline Ophtalmological department & 10 & 3,00 \\
\hline Rehabilitation ward & 8 & 2,40 \\
\hline Infectious disease ward & 14 & 4,30 \\
\hline Other & 28 & 8,50 \\
\hline \multicolumn{3}{|l|}{ Seniority [years] } \\
\hline$<1$ & 8 & 2,40 \\
\hline $1-4$ & 39 & 11,80 \\
\hline $5-9$ & 41 & 12,40 \\
\hline $10-14$ & 31 & 9,40 \\
\hline$>15$ & 211 & 63,90 \\
\hline
\end{tabular}

$\mathrm{N}$-number of respondents, \%-percentage
Table 2. Descriptive statistics of the subjects' knowledge

\begin{tabular}{lcccccccc}
\hline & N & M & SD & Min & Maks & Q25 & Me & Q75 \\
\hline Knowledge & 330 & 4,44 & 2,33 & 0,00 & 12,00 & 2,00 & 5,00 & 6,00 \\
\hline Knowledge \% & 330 & 37,05 & 19,47 & 0,00 & 100,00 & 17,00 & 42,00 & 50,00 \\
\hline
\end{tabular}

$\mathrm{N}$ - number of respondents; M - average; SD - standard deviation; Min - minimum; Maks - maksimum; Q25 - first quartile; Me - mediana; Q75 - third quartile

fifth respondent indicated neurological complications, and every fourth stressed the exacerbation of chronic diseases. Among flu prevention measures, the staff surveyed most often mentioned proper hygiene procedures (64.13\%) and protective vaccinations (33.74\%). Nearly 15\% (14.29\%) mentioned pharmacological prophylaxis which, however, is not recommended in routine procedures. According to $76.40 \%$ of the respondents, there are contraindications for vaccination against influenza. It is worrying that among the contraindications, in addition to infection with fever and intolerance to the vaccine component, the respondents listed planning to or actually being pregnant (34.7\%).

Subsequently, attempts were made to determine whether gender had an impact on the level of knowledge. $47.8 \%$ women and $45.9 \%$ men had a low level of knowledge. The average level of knowledge was found in $42.3 \%$ women and $37.8 \%$ men, while $9.9 \%$ women and $16.2 \%$ men revealed a high level of knowledge. There was no relationship between the level of knowledge and the gender of the respondents ( $p>0.05$ ).

In the next stage, the level of knowledge depending on age was analysed. $30.90 \%$ of the respondents were under the age of 40 , in the group of persons aged $40-49$ and $>50$ years the percentage was the same and amounted to $34.50 \% .51 .0 \%$ of the respondents under the age of 40 had a low level of knowledge, $45.6 \%$ of those aged between $40-49$, and $46.5 \%$ of those aged 50 . On the other hand, $16.7 \%$ of the respondents under the age of $40,5.3 \%$ at the age of $40-49$ and $10.5 \%$ over 50 , presented a high level of knowledge. Respondents under 40 years of age significantly more often had a high level of knowledge $(\mathrm{p}<0.05)$ (Tab. 3).

Table 3. The relationship between the level of respondents) knowledge and age

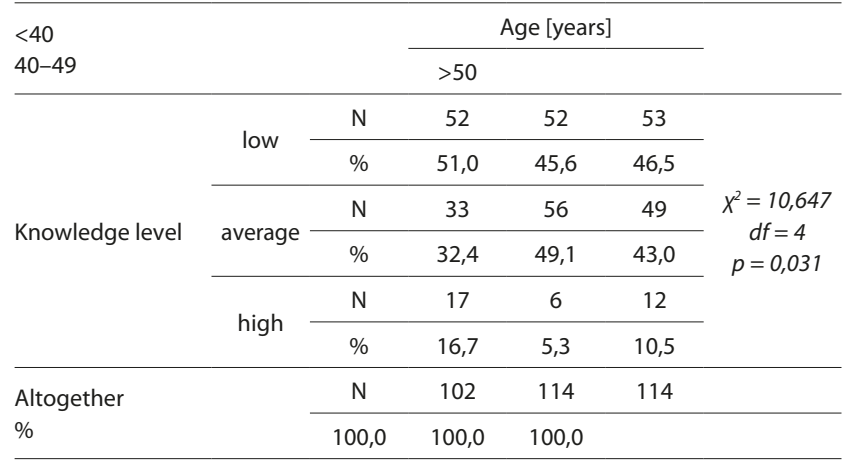

$\mathrm{X} 2$ - test statistic; $\mathrm{df}$ - degrees of freedom; $\mathrm{p}$ - statistical significance

Subsequently, the level of knowledge depending on occupation was examined. $10.3 \%$ of nurses and $11.5 \%$ of the respondents working in another medical sphere had a high level of knowledge, whereas $44.0 \%$ of nurses and $57.5 \%$ of other professionals had a low level of knowledge. The differences, however, were not statistically significant (p>0.05) (Tab. 4). 
Table 4. The relationship between the level of respondents' knowledge and the profession

\begin{tabular}{|c|c|c|c|c|c|}
\hline $\begin{array}{l}\text { Nurse } \\
\text { Other }\end{array}$ & & & \multicolumn{2}{|c|}{ Profession } & \\
\hline \multirow{6}{*}{ Knowledge level } & \multirow{2}{*}{ low } & $\mathrm{N}$ & 107 & 50 & \multirow{6}{*}{$\begin{array}{c}x^{2}=5,805 \\
d f=2 \\
p=0,055\end{array}$} \\
\hline & & $\%$ & 44,0 & 57,5 & \\
\hline & ayera & $\mathrm{N}$ & 111 & 27 & \\
\hline & ave & $\%$ & 45,7 & 31,0 & \\
\hline & \multirow{2}{*}{ high } & $\mathrm{N}$ & 25 & 10 & \\
\hline & & $\%$ & 10,3 & 11,5 & \\
\hline \multirow{2}{*}{$\begin{array}{l}\text { Altogether } \\
\%\end{array}$} & & $\mathrm{~N}$ & 243 & 87 & \\
\hline & & 100,0 & 100,0 & & \\
\hline
\end{tabular}

$\mathrm{X} 2$ - test statistic; $\mathrm{df}$ - degrees of freedom; $\mathrm{p}$ - statistical significance

Table 5. The relationship between the level of knowledge of the respondents and education

\begin{tabular}{|c|c|c|c|c|c|}
\hline $\begin{array}{l}\text { Secondary } \\
\text { High }\end{array}$ & & & \multicolumn{2}{|c|}{ Education } & \\
\hline \multirow{6}{*}{ Knowledge level } & \multirow{2}{*}{ low } & $\mathrm{N}$ & 80 & 77 & \multirow{6}{*}{$\begin{array}{c}x^{2}=8,672 \\
d f=2 \\
p=0,013\end{array}$} \\
\hline & & $\%$ & 49,4 & 45,8 & \\
\hline & & $\mathrm{N}$ & 73 & 65 & \\
\hline & average & $\%$ & 45,1 & 38,7 & \\
\hline & \multirow{2}{*}{ high } & $\mathrm{N}$ & 9 & 26 & \\
\hline & & $\%$ & 5,6 & 15,5 & \\
\hline \multirow{2}{*}{$\begin{array}{l}\text { Altogether } \\
\%\end{array}$} & & $\mathrm{~N}$ & 162 & 168 & \\
\hline & & 100,0 & 100,0 & & \\
\hline
\end{tabular}

$\mathrm{X} 2$ - test statistic; $\mathrm{df}$ - degrees of freedom; $\mathrm{p}$ - statistical significance

Secondary education, including vocational, was declared by $49.10 \%$ of those surveyed, while a bachelor's and master $s$ degree by $50.90 \% .49 .4 \%$ of the respondents with secondary education and $45.8 \%$ with higher education had a low level of knowledge. On the other hand, $5.6 \%$ of people with secondary education and $15.5 \%$ with higher education presented a high level of knowledge. Persons with higher education were significantly more likely to have a high-level of knowledge about flu vaccination (Tab. 5).

The respondents were asked whether the workplace surgical $(26.70 \%)$ or conservative $(73.30 \%)$ department, affects the level of knowledge. A low level of knowledge was found in $52.3 \%$ of the respondents employed in surgical departments and in $46.1 \%$ of those employed in conservative departments. On the other hand, 9.1\% of the employees of surgical departments and $11.2 \%$ of conservative departments had a high level of knowledge. The differences, however, were not statistically significant ( $\mathrm{p}>0.05)$.

Considering the seniority of the respondents, it was found that $49.6 \%$ of those who had work for less than 15 years and $46.4 \%$ of those who had worked for more than 15 years had a low level of knowledge. $14.3 \%$ of the persons with seniority below 15 years and $8.5 \%$ with seniority over 15 years had knowledge at a high level. The differences were, however, not statistically significant ( $\mathrm{p}>0.05$ ).

When analysing the replies to questions regarding the attitudes and beliefs of the respondents about influenza vaccination, it was found that only every third respondent
Table VI. Detailed description of the answers provided

\begin{tabular}{|c|c|c|}
\hline Supporter of influenza vaccination & $\mathbf{N}$ & $\%$ \\
\hline Yes & 110 & 33,30 \\
\hline No & 220 & 66,70 \\
\hline \multicolumn{3}{|l|}{ Flu vaccination in current season } \\
\hline Yes & 58 & 17,60 \\
\hline No & 272 & 82,40 \\
\hline \multicolumn{3}{|l|}{ Vaccination } \\
\hline Annually & 43 & 13,00 \\
\hline Occasionally & 56 & 17,00 \\
\hline First time this season & 9 & 2,70 \\
\hline Never & 222 & 67,30 \\
\hline \multicolumn{3}{|c|}{ Willingness to vaccinate if it was refunded } \\
\hline Yes & 109 & 33,00 \\
\hline No & 221 & 67,00 \\
\hline \multicolumn{3}{|c|}{ Do you recommend influenza vaccination? } \\
\hline Always & 31 & 9,40 \\
\hline Often & 66 & 20,00 \\
\hline Seldom & 76 & 23,00 \\
\hline Never & 157 & 47,60 \\
\hline \multicolumn{3}{|c|}{ Inclusion of free vaccinations in the workplace } \\
\hline Yes & 180 & 54,50 \\
\hline No & 150 & 45,50 \\
\hline \multicolumn{3}{|l|}{ Fear of getting the flu } \\
\hline Yes & 132 & 40,00 \\
\hline No & 198 & 60,00 \\
\hline
\end{tabular}

Work despite symptoms indicative of a current respiratory infection

\begin{tabular}{lcc}
\hline Never & 56 & 17,00 \\
\hline Seldom & 201 & 60,90 \\
\hline Often & 73 & 22,10 \\
\hline Do you think that you are at risk of influenza? & & \\
\hline Yes & 204 & 61,80 \\
\hline No & 126 & 38,20 \\
\hline
\end{tabular}

\section{Why flu vaccination?}

\begin{tabular}{lccc}
\hline According to reccomendations & 17 & 24,64 \\
\hline I m vaccinated every year & 25 & 36,23 \\
\hline I care about my health & 34 & 49,28 \\
\hline I care about my relatives health & 18 & 26,09 \\
\hline I care about may patients health & 9 & 13,04 \\
\hline
\end{tabular}

\section{Reasons for the lack of vaccination decision}

\begin{tabular}{lcc}
\hline No evidence of the effectiveness of the vaccine & 51 & 19,25 \\
\hline The conviction of low effectiveness & 130 & 49,06 \\
\hline Fear of an adverse reaction to vaccination & 55 & 20,75 \\
\hline Lack of time & 30 & 11,32 \\
\hline The need to pay & 13 & 4,91 \\
\hline Fear of injection & 12 & 4,53 \\
\hline Other & 14 & 5,28 \\
\hline
\end{tabular}

$\mathrm{N}$-number of respondents, \%-percentage

was in favour of vaccination. Slightly over $15 \%$ of respondents (17.60\%) declared that they had been vaccinated against influenza in the current 2018-2019 season. The vast majority of respondents replied that they had never been vaccinated 
against influenza, and only $13 \%$ said they were vaccinated every year. One in three would consider vaccinating if it was refunded. Almost half of the respondents replied that they never recommended vaccinating to their patients. $54.5 \%$ of the respondents said they could get a flu vaccination free of charge in the workplace. Most respondents (60\%) were not afraid of getting the flu, despite the fact that $61.80 \%$ thought they were at risk. Only $17.00 \%$ of the respondents said that they never undertook work while having the symptoms of flu infection. Nearly half of the respondents $(49.06 \%)$ voiced the belief that the vaccine was of low effectiveness as justification for the lack of vaccination (Tab. 6).

\section{DISCUSSION}

Annual vaccination is the most effective way to prevent and control the health and economic effects associated with getting influenza [8]. Health care professionals play a key role in promoting the vaccination and setting an example to their patients. Vaccination against influenza should be administered to protect oneself and family against falling ill and spreading the virus into the home environment, and to protect patients from falling ill.

The subject of mandatory vaccination against influenza among health care professionals, however, raises much controversy and is full of ethical and legal implications. While some researchers maintain that patient protection is the responsibility of hospitals, and hence the vaccination of employees against influenza should be mandatory [9], other researchers argue that the lack of scientific reports confirming the effectiveness of vaccination and, as such, mandatory vaccination against influenza remains a challenge for health care professionals and remains an open issue $[10,11]$.

The decision to use vaccinations is influenced by another aspect, often highlighted in publications - the ethical aspect. Some researchers believe that if vaccinated personnel rates are not optimal and campaigns promoting vaccinations are fruitless, mandatory vaccination policies may be introduced. The report from the survey of the National Programme for Combating Influenza (OPZG) stated that a significant proportion of health care workers do not perceive a relationship between the incidence of influenza and health, and the possibility of transmitting the disease to patients [12]. This is confirmed by the research of the authors of the current survey, where most respondents were not afraid of getting the flu. Therefore, it is suggested that there should be a moral order to carry out vaccination in the group of health care workers [13-15]. In the research by Gołębiak et al. [16], the respondents were asked about the ethical nature of influenza vaccination. The results showed that $83 \%$ of the staff working in outpatient departments accept the ethical aspect of vaccination; in the group of hospital employees it was $55 \%$, which in total for all the respondents amounted to $66 \%$ of respondents [16].

The literature increasingly emphasizes a better understanding of the psycho-social determinants of the personal decision to get vaccinated against influenza [17]. A number of studies on decision models have been developed to assess vaccination predictive factors. According to these models, the decision to get vaccinated against influenza is mainly due to the belief that the susceptibility to influenza infection is high, and that influenza is a serious infectious disease, whereas the lack of vaccination is due to the belief that vaccination has serious side effects and is not effective $[18,19]$. In own study, in the group of persons who declared that they had been vaccinated, almost a half (49.28\%) stated that they got vaccinated because they cared about their health, over $25.0 \%$ of the respondents said that they got vaccinated because they cared about the health of their families, and $13.04 \%$ because they cared about the health of their patients. However, in the group of the non-vaccinated persons, the most frequently cited reason for such a decision was the belief that the vaccine>s effectiveness was low (49.06\%).

Despite almost 10 years of efforts and extensive campaigns to vaccinate health care professionals in most European countries, vaccination coverage is still low in this group [20]. In own study, the percentage of vaccinated persons was similar to Italian studies, but considerably lower than in other countries, such as the United States (90.5\%), the United Kingdom (68.7\%), and other European countries (40\%-45\%)[20-25].

The results of research by Harris et al. showed that a higher vaccination rate against influenza occurred in the situation of legal fortifications resulting from internal regulations of the health care facility, activities promoting vaccination, and the possibility of administering the vaccination free of charge for a period longer than one day [26]. In own research, only every third person would have had themselves vaccinated if the vaccine had been refunded.

In Poland, there is little data on the vaccination status of medical personnel and reports assessing knowledge and allowing to get to know the opinion of healthcare workers about influenza vaccination. However, studies available in the literature show that relatively few medical workers undergo vaccination [14]. The results of the current survey indicate that there is a need to improve the level of support for seasonal influenza vaccination among health care workers. This is due to the fact that only every third respondent is in favour of vaccination, and in the current season (2018-2019) only $17.6 \%$ declared that they have been vaccinated, and only $13 \%$ are vaccinated annually. Similar results were obtained by Sternal and Owsianko, stating that $20.2 \%$ of their respondents performed irregular vaccinations, while $12.5 \%$ of the respondents had themselves vaccinated regularly every year [27]. Of particular concern is the fact that in Poland a small part of the nursing staff is vaccinated, and it is the nurse who is the person who has the most frequent contact with patients $[16,27,28]$. In the literature, the main reason for such a small group of workers undergoing vaccination is the lack of adequate knowledge about this type of flu prevention $[14,28]$. In own research, vaccination as a prevention measure against influenza was reported by just over $30 \%$ of employees. The need to educate and promote health prevention rests on the shoulders of all health care professionals. It is advisable that this education should be properly organized, purposeful and, regular, and the attitudes presented by the interdisciplinary team well grounded and based on current medical knowledge and the recommendations of international organizations [29].

However, own research has shown that knowledge about seasonal influenza vaccination is low, and only every fourth person surveyed acted in accordance with the recommendations. Financial considerations are one of the important reasons for not vaccinating medical staff $[16,27]$. In own study, the need to pay for the vaccinations is given 
by $15.50 \%$ as the reason for not vaccinating. The impact of funding on vaccination is confirmed by American studies, where the vaccination rate was the lowest among medical workers whose employers did not require vaccinations, did not promote them, and did not provide free access to vaccines [30]. The results of the survey conducted among employees of medical facilities under the OPZG project indicate that one of the main factors determining the implementation of preventive vaccinations is providing free access to them at the workplace. Only every third respondent declared that their employer runs free vaccinations for medical staff before and during the flu epidemic season [31]. In own study, however, more than half of the respondents declared that they had access to free vaccination in the workplace, and yet they did take advantage of this type of preventive measure. At the same time, less than $5.0 \%$ of the respondents (4.91\%) mentioned the necessity to pay as an argument for not being vaccinated. Another recurring reason why health care professionals do not get vaccinated against influenza is the fear of the vaccine and its adverse effect - Vaccine Adverse Effect (VAE) [14]. In the publication by Gołębiak et al., the fear of VAE was brought up as the argument by $31 \%$ of the personnel for not being vaccinated [16]. In the study by nSternal et al., $16 \%$ of the respondents expressed anxiety about VAE [27], and in own study, every fifth person reported the fear of VAE as the reason for deciding not to get vaccinated.

\section{CONCLUSIONS}

1) Healthcare professionals' knowledge of influenza and seasonal vaccinations is incomplete.

2) Few healthcare workers are vaccinated against influenza in the Cieszyn poviat.

3) The main reason for getting vaccinated is the desire to protect oneself against the illness, while the reason for not getting it is the lack of trust in the vaccine's effectiveness.

4) A significant percentage of healthcare workers surveyed do not recommend seasonal influenza vaccination for their patients.

5) There is a need to increase efforts to promote annual influenza vaccination among healthcare workers in Cieszyn County of the Silesian Province.

In conclusion, it should be noted that there are many factors behind the decision for or against influenza vaccination. The observations obtained may serve as a voice in the discussion on the need to improve educational activities in the field of preventive vaccinations among health care workers. Therefore, it is worth focusing on effective education that will allow the creation of a positive attitude and form favourable opinions about vaccinations, which will result in the decision to undergo regular vaccination.

\section{REFERENCES}

1.Bednarska K, Hallmann-Szelińska E, Kondratiuk K, Brydak LB. Influenza surveillance. Postepy Hig Med Dosw. 2016; 70: 313-318. DOI: $10.5604 / 17322693.1199709$

2. World Health Organization. Influenza (Seasonal). https://www.who.int/ news-room/fact-sheets/detail/influenza-(seasonal) (access: 05.05.2019).

3. Brydak LB. Skutki zdrowotne i ekonomiczne zakażeń grypą w aspekcie zdrowia publicznego. Pol Prz Nauk Zdr. 2016; 4(49): 401-407.
4. Mereckiene J. European Centre for Disease Prevention and Control. Seasonal influenza vaccination in Europe: overview of vaccination recommendations and coverage rates in the EU Member States for 2012-2013 influenza season. Stockholm: ECDC; 2015. ISBN 978-929193-618-2. DOI 10.2900/693898

5.CDC: Immunization of health-care personnel: recommendations of the Advisory Committee on Immunization Practices (ACIP). MMWR. Recommendations and reports: Morbidity and mortality weekly report. Recomm Rep. 2011; 60 (RR-7): 1-45.

6. Announcement of the Chief Sanitary Inspector of 25th October 2018 regarding the Protective Vaccination Program for 2019. Dz. Warsaw, on 25th October 2018. Item 104

7. Nitsch-Osuch A, Brydak LB. Szczepienia przeciwko grypie u personelu medycznego. Med Pr. 2013; 64: 119-129. https://doi.org/10.13075/ mp.5893/2013/0011

8. Wilde JA, McMillan JA, Serwint J, Butta J, O’Riordan MA, Steinhoff MC. Effectiveness of influenza vaccine in health care proffessionals: a randomized trial. JAMA 1999; 281: 908-913. DOI: 10.1001/ jama.281.10.908

9. Wicker S, Marckmann G. Vaccination of health care workers against influenza: Is it time to think about a mandatory policy in Europe? Vaccine 2014; 32(38): 4844-4848. DOI: 10.1016/j.vaccine.2013.09.062

10. Hulo S, Nuvoli A, Sobaszek A, Salembier-Trichard A. Knowledge and attitudes towards influenza vaccination of health care workers in emergency services. Vaccine 2017; 35(2): 205-207. DOI: 10.1016/j. vaccine.2016.11.086

11. Randall LH, Curran EA, Omer SB. Legal considerations surrounding mandatory influenza vaccination for healthcare workers in the United States. Vaccine 2013; 31(14): 1771-1776. DOI: 10.1016/j. vaccine.2013.02.002

12. Kmiecik T, Otocka-Kmiecik A, Ciebiada M, Górski P. Vaccinations against influenza in groups of risk - Polish and global recommendations. Med Dypl. 2009; 8(161): 55-60.

13. Johnson DR, Nichol KL, Lipczyński K. Barriers to adult immunization. Am J Med. 2008; 121: 28-35. DOI: 10.1016/j.amjmed.2008.05.005

14. Grzela AM, Panczyk M, Gotlib J. The opinions of health care employees on vaccinating against influenza - preliminary reports. Piel Pol. 2016; 2(60): 158-164.

15. Ethics of mandatory vaccination for healthcare workers. https://pdfs. semanticscholar.org/4cab/706c4b2aa42481c40c59f7517f85fe51cf8b.pdf (access: 14.01.2019).

16. Gołębniak I, Pulkowska-Nowocień A, Topczewska-Cabanek A, Dawgiałło M, Życińska K, Nitsch-Osuch A. Knowledge, perception and the execution of vaccinations against influenza among the nursing Staff. Fam Med Prim Care Rev. 2015; 17(1): 15-18.

17. To KW, Lai A, Lee KCK, Koh D, Lee SS. Increasing the coverage of influenza vaccination in healthcare workers: review of challenges and solutions. J Hosp Infect. 2016; 94: 133-142. DOI: 10.1016/j. jhin.2016.07.003

18. Becker MH, Maiman LA. Sociobehavioral determinants of compliance with health and medical care recommendations. Med Care. 1975; 13: $10-24$.

19. Ajzen I. The theory of planned behavior. Organ Behav Hum Decis Process. 1991; 50: 179-211, https://doi.org/10.1016/0749-5978(91)90020-T

20. Mereckiene J, Cotter S, Nicoll A, Lopalco P, Noori T, Weber J, et al. Seasonal influenza immunisation in Europe. Overview of recommendations and vaccination coverage for three seasons: prepandemic (2008/09), pandemic (2009/10) and post-pandemic (2010/11). Euro Surveill 2014; 19(16): 20780; https://doi.org/10.2807/1560-7917. ES2014.19.16.20780

21. Maggiore UL, Scala C, Toletone A, Debarbieri N, Perria M, D'Amico B, Montecucco A, Martini M, Dini G, Durando P. Susceptibility to vaccinepreventable diseases and vaccination adherence among healthcare workers in Italy: A cross-sectional survey at a regional acute-care university hospital and a systematic review. Hum Vaccin Immunother. 2017; 13(2): 470-476, https://doi.org/10.1080/21645515.2017.1264746

22. Black CL, Yue X, Ball SW, Fink RV, de Perio MA, Laney AS, Williams WW, Graitcer SB, Fiebelkorn AP, Lu PJ, et al. Influenza vaccination coverage among health care personnel-United States, 2017-2018 Influenza Season. Morb Mortal Wkly Rep. 2018; 67: 1050-1054.

23. Public Health England. Seasonal influenza vaccine uptake amongst frontline healthcare workers (Hcws) in England: February Survey 2017/2018. 2018. Available online: https: //assets.publishing.service.gov. uk/government/uploads/system/uploads/attachment_data/file/692969/ Seasonal_Flu_Vaccine_February_Report_2018.pdf(access: 28.11.2019).

24. Boey L, Bral C, Roelants M, De Schryver A, Godderis L, Hoppenbrouwers $\mathrm{K}$, Vandermeulen C. Attitudes, believes, determinants and 
organisational barriers behind the low seasonal influenza vaccination uptake in healthcare workers-A cross-sectional survey. Vaccine 2018; 36: 3351-3358.

25. Hagemeister MH, Stock NK, Ludwig T, Heuschmann P, Vogel U. Selfreported influenza vaccination rates and attitudes towards vaccination among health care workers: Results of a survey in a German university hospital. Public Health 2018; 154: 102-109.

26. Harris K, Maurer J, Black C, Euler G, Kadiyala S. Workplace efforts to promote influenza vaccination among healthcare personnel and their association with uptake during the 2009 pandemic influenza A (H1N1) Vaccine. 2011; 29: 2978-85. DOI: 10.1016/j.vaccine.2011.01.112

27. Sternal D, Owsianko A. Opinie personelu medycznego na temat zalecanych szczepień przeciwko grypie. Med Og Nauk Zdr. 2019; 25(1): 16-21. https://doi.org/10.26444/monz/104752
28.Zielonka TM, Lesiński J, Życińska K, Machowicz R, Królikowski K, Wardyn AK. Vaccinations against influenza among the medical staff of research and teaching hospitals in Warsaw and students of the Medical University of Warsaw. Med Pr. 2009; 60(5): 369-375.

29. Bednarek A, Zarzycka D. The need for and the assumptions of modern education illustrated with the example of preventive vaccinations. Probl Hig Epidemiol. 2015; 96 (1): 1-7.

30. Influenza Vaccination Coverage Among Health Care Personnel United States, 2016-17 Influenza Season. https: // www. cdc.gov/mmwr/ volumes/66/wr/mm6638a1.htm (access: 04.01.2019).

31. Vaccination against influenza among healthcare workers in Poland - present and future prospects. Analysis of the results of the survey conducted among healthcare workers (the report was created as part of the implementation of the National Program for Combating Flu. www.opzg.pl 